\title{
Editorial: Joining the Conversation
}

\author{
PAUL RAE
}

In my previous editorial, I made reference to what Theresa Lillis and Mary Jane Curry call 'literacy brokering' amongst non-native speakers of English who seek to publish in anglophone academic journals. ${ }^{1}$ The term 'literacy' makes sense in the context, and, as I noted, the practice is hardly exclusive to those whose first language is not English. However, as Aoife Monks of Contemporary Theatre Review and I planned a New Scholars session on academic publishing for this year's annual conference of the International Federation for Theatre Research (IFTR, with which this journal is affiliated), a supplementary way of thinking about academic knowledge production came to mind: as conversation. And it is a conversational mode that wends its way through the articles presented in this issue of Theatre Research International.

Oral and open-ended, on the face of it conversations are radically at odds with the rigorously drafted and materially discrete journal article. But researching, interpreting and explaining performance reminds us of the shortcomings of such a distinction. Indeed, the IFTR conference was itself an excellent example of the roles that diverse modes of interaction, operating at varying degrees of formality and in multiple languages, play in the development and circulation of performance knowledge. There, as elsewhere, conversations traversed scholarly and social settings. At their best, panels and working groups afforded focused opportunities for the progressive refinement of positions as they were tempered by the provisional responses of interlocutors. Meanwhile, more casual interactions allowed ideas to freewheel through all kinds of other subject matter and non-verbal dimensions, charging them as they went with a social identity and a firm anchoring in the material world.

Of course, it would be naive to think that conversations are always meetings of equals: when people enter what Erving Goffman winningly called the 'ecological huddle' of the microsocial situation, they do not leave power differentials behind, especially not in circumstances informed by professional hierarchies and wide variations in competence in the lingua franca. ${ }^{2}$ Moreover, I think we all have had - and probably continue to have experiences where we feel like we are the only person in a room of conference-goers who does not know anyone, or who is not part of a series of ongoing discussions, periodically rejoined in multiple locations over time, and deeply rooted in shared experiences and tacit understandings. But conversations can grow stale without new stimulus. And if the situation is not a gathering of peers, the conversation is liable to go elsewhere, or else be reasserted as a necessarily 'difficult conversation', where power is contested and terms are renegotiated - or indeed, as in certain kinds of scholarly activism such as 'no-platforming', foreclosed. 
IFTR's New Scholars bursaries and events provide a series of opportunities for participants to enter the conversations of the conference and of the field, and to open new conversations that will in some cases last a professional lifetime. In their combination of socializing, presentation and debate, they also offer a concentrated representation of how we might think about the development of academic knowledge more broadly. In parlance all too common in the contemporary university, 'writing time' is a rare luxury that academics increasingly feel the need to 'protect' against other demands. But it would be a shame if we ceased to recognize the extent to which writing emerges out of, and is continuous with, countless conversational interactions with artists, collaborators, peers, mentors, publics and - whether they like it or not - friends and family. Ideally, the critical engagement with scholarly interlocutors within writing sustains something of this mode, as does the editorial process; in turn, the article makes its own contribution to an ongoing conversation. And whether it comprises new information, bold intervention, gentle reinflection or a change in tone or direction, one thing it is unlikely to be is the last word on any matter.

Each of the articles in this issue reflects, or reflects on, these processes differently. We begin with Partha Chatterjee's 'Theatre and the Publics of Democracy: Between Melodrama and Rational Realism'. Chatterjee is a renowned anthropologist and historian whose article is based on the keynote speech he delivered at the IFTR conference in Hyderabad, India, in 2015. As such, the article suggests how a dialogue might be opened between theatre and performance studies, with a major scholar from a different disciplinary background. Writing in an essayistic style that carries over some of the oral qualities of the initial presentation, Chatterjee presents a broad, bold historical narrative that spans multiple decades, and several key moments in the history of theatre in various regions in India. In so doing, he seeks to trace how the aesthetic forms and social formations of theatre moved in and out of alignment with democratic structures and the interests of capital in the course of the twentieth century. In particular, Chatterjee frames a narrative of theatrical developments in the diverse regions of India within the context, after Benedict Anderson's concept of 'print capital', of 'performance-capitalism'. Reflecting technological advances in the means of production and transmission, 'performance-based cultural commodities' were increasingly able to forge 'a unified although internally differentiated public attuned to the textual, visual and aural practices of modern dramatic narration'. In the contemporary context, notes Chatterjee, theatre occupies only a small part of this mode of production, which on the one hand marginalizes it, but on the other grants a degree of flexibility in how it might be positioned and understood. Specifically, Chatterjee argues that the limitations of theatre's address, by comparison with the mass media, in fact provide an opportunity for it to speak to a diversity of discrete audiences, each relatively homogeneous in its composition. This proposal runs somewhat counter to more established understandings of democracy within theatre studies, where we often find an investment in showing how theatrical narratives stage democratic debates in microcosm, or how theatre's organizational and aesthetic forms either exemplify democratic practices, or make an unequivocal assertion in the spirit of radical democratic provocation. It is perhaps apt that Chatterjee's own view, born of locating theatrical practice within the wider ambit of his historical and 
political concerns, comes as something of a challenge to what disciplinary consensus may exist within theatre studies. The article invites critical engagement, and perhaps disciplinary dissent - and in so doing, it enacts what it is about.

Dissent of a more socially direct kind animates the theatre practices discussed in Kelvin Chikonzo's article, 'From Panic to Reconciliation: Protest Theatre and the State in Zimbabwe, 1999-2012'. Chikonzo outlines the different forms that protest theatre took in response to the political upheavals experienced in Zimbabwe from the beginning of the present century. Set against a backdrop of sometimes murderous political violence, what is interesting is that even when protest theatre-makers have adopted an oppositional stance towards the state or the status quo, they have done so in the name of a conventionally deliberative goal: democratic participation by an informed citizenry. In an argument that intersects intriguingly with Chatterjee's reflections on theatre's marginalization within India's media landscape, Chikonzo shows that it was the increasing monopolization of the mass media by the Zimbabwean state under President Robert Mugabe that first prompted numerous theatre-makers to create protest theatre, in order to keep alternative political narratives alive in the public domain. Multiple protest forms followed in quick succession, leading, in Chikonzo's account, to the somewhat paradoxical concept of 'reconciliation protest theatre'. After a contentious and highly divisive electoral process in 2008, a government of national unity was formed and set about a process of reconciliation. However, the terms on which reconciliation was to be realized were limited. Chikonzo analyses a number of plays created during this period that sought to nuance the process by confronting past atrocities more directly, while at the same time adding popular and folk narratives to the arsenal of means by which their legacies might be addressed.

Lee Hyunjung's 'An Eternal Parting: Staging Internal Diaspora, Performing South Korean Nationalism' is also preoccupied with the scope for expressing complex and diverse experiences and world views within state-sanctioned narratives. In the case of South Korea, however, dance theatre company Movement Dang-Dang's performance An Eternal Parting (2011 and 2013) sought to address legacies of violence that stretches back through the twentieth century and encompasses colonialism, displacement, ethnic purges and war. It was as a result of those events that a Korean diaspora spread across Japan, China, Russia and parts of South America, and it is the experience of those diasporic Koreans and their descendants who have now settled in South Korea that Movement Dang-Dang explored in their performance. In order to develop the work, the artists spent time with the various communities that comprise this 'internal diaspora' within Seoul, interviewing them and learning about their lives and aspirations. Lee aims to show how An Enternal Parting sought to communicate those discoveries to a native-born South Korean audience whose relative homogeneity has tended to shield them from questions about the relationship between language, nation, place, belonging and ethnicity. However, Lee also argues that, ultimately, the artists' well-intentioned conversations with Seoul's disaporic Korean communities were not successfully communicated in performance, where the tropes of a powerful, singularizing, South Korean nationalism ultimately proved too strong, skewing the performance towards the reiteration and reassertion of a dominant narrative ill-equipped to accommodate difference. Lee does go on to note one exception 
to that tendency: the inclusion in An Eternal Parting of a YouTube video clip in which a Belgium-based Korean dancer on tour in Colombia improvised a performance in his hotel room to a traditional Korean folk song. Lee argues that the inventive and affecting clip mobilizes nationalist tropes in ways that simultaneously recognize their persistence, and complicate their meanings and effects.

The use of technology both to offset live performance and to contribute to its affective force is also a concern in Suzanne Little's 'Dramaturgies of the Left-Behind: Mobility and Stickiness in The Disappearances Project'. Like Lee, Little reflects extensively on a single performance - in this case, The Disappearances Project (2011-13), by Australian company Version 1.0 - to examine what performance can tell us about the experience of displacement. While the members of the erstwhile Korean diaspora in Lee's article are 'returnees' to a homeland in which they had never lived, in Little's article the focus is the friends and family members of missing persons, who suddenly find themselves estranged in their own homes by the abrupt and open-ended absence of those with whom they had hitherto shared their lives, and forged their identities. In the performance, seated actors voiced the verbatim testimony of the 'left-behind' before projected video footage, shot through a car window, of a circuitous journey - and apparently fruitless search - through a suburban nightscape. It is in the juxtaposition of these statically delivered narratives of indefinite waiting, and the restless roving of the video projections, that Little locates the source of the performance's powerful effects upon an audience, in turn prompting a series of reflections on the implications of mobility theory for theatre and performance studies.

The final article in this issue, Felipe Cervera's 'Astroaesthetics: Performance and the Rise of Interplanetary Culture', takes the 'mobility turn' to a logical extreme by examining the performative dimensions of what is sometimes called 'NewSpace': post-national space programmes pursued by corporations and entrepreneurs for purposes of resource extraction, commercial exploitation, and leisure and entertainment, accompanied by the emergence of a new generation of space powers such as China. Cervera surveys the varied manifestations of such developments on Earth and in Space, asking both what this means for performance, and how performance studies can contribute to the critical interpretation of such activities and their meanings for our planetary self-understanding. Cervera's examples stretch from a Mexican play about the first child born on the Moon, which also functions as a satire on Mexico's relationship with the United States, to the Mars One project, which proposes to make reality television out of casting, equipping and broadcasting the first humans to live and die on the red planet. He ends, though, on a more modest project: a sound installation by artistic collective $\mathrm{r}$ a $\mathrm{d}$ i o $\mathrm{q}$ u a $\mathrm{l}$ i a entitled Radio Astronomy (2004-), which affords the listener what Cervera describes as 'an experience of interplanetary synaesthesia and cosmological delay'. 'I am barely starting to learn how to listen', he writes, after first tuning in to Radio Astronomy, which he argues offers a challenging but important counternarrative to the boosterish machismo of many 'NewSpace' discourses. Here, the one-way conversation of The Disappearance Project's 'left-behind' expands to encompass all those on this planet who would commune with the stars, and who in turn find an answering echo in $\mathrm{r}$ a $\mathrm{d}$ i o $\mathrm{qu}$ a l i a's transformation of electromagnetic waves into sound. 
Meanwhile, back at TRI mission control, the conversations and other interactions to which these articles testify continue apace, or else draw to a close. In the course of corresponding with Kelvin Chikonzo on his article for this issue, I could not help but be aware that a new protest movement was gathering pace in Zimbabwe. In April 2016, a pastor, Evan Mawarire, posted a video on Facebook expressing his frustration at the nation's political and economic situation. Mawarire wore the Zimbabwean flag draped over his shoulders, and the video went unexpectedly viral, with the \#ThisFlag protest movement quickly gathering momentum on social media and in the streets. At the same time as Mawarire's posting, as Chikonzo mentions in the conclusion of his article, actor Silvanos Mudzvova was detained by the authorities for staging his protest performance Missing Diamonds: I Want My Share outside the Parliament Building. Both Mawarire and Mudzvova were responding, among other things, to an admission by President Mugabe that $\$ 15$ billion in revenue from Zimbabwe's diamond mines, which were part-owned by Chinese companies, had gone missing. At the time of writing, unrest in Zimbabwe's urban centres is ongoing. On the other hand, Felipe Cervera wrote recently to report that since submitting the final draft of his article, Jade Rabbit, the Chinese moon rover which became a social media 'celebrity' after a series of poetic postings in its name narrating its 'life' and near-death experiences on the Moon, had finally ceased operating, though not, according to China's State Administration for Science, Technology and Industry for National Defense (SASTIND), before contributing data to over a hundred scientific papers. ${ }^{3}$ We are forever striking up in medias res (in the middle of things), and we leave off there, too. 'Conversation' is one name for what we do in between times, and occasionally it coalesces into something like the articles that populate this issue.

NOTES

1 Theresa Lillis and Mary Jane Curry, Academic Writing in a Global Context: The Politics and Practices of Publishing in English (Abingdon and New York: Routledge, 2010), p. 87.

2 Erving Goffman, 'The Neglected Situation', American Anthropologist, 66, 6 (1964), pp. 133-6, here p. 135.

3 Jacob Aron, 'China's Jade Rabbit Moon Rover Dead after 31 Months on Surface', New Scientist, 3 August 2016, available at www.newscientist.com/article/2099696-chinas-jade-rabbit-moon-rover-dead-after31-months-on-surface, accessed 28 August 2016. 